\title{
PENGARUH KOMPETENSI, DISIPLIN KERJA DAN PENGALAMAN KERJA TERHADAP KINERJA KEPALA SEKOLAH DASAR SE KABUPATEN BIREUEN
}

\author{
Ibnu Hibban ${ }^{1)}$ dan M. Yusuf ${ }^{2 *}$ ) \\ ${ }^{1}$ Pegawai Dinas pendidikan dan Kebudayaan Kabupaten Bireuen - Aceh \\ 2, Dosen FE Universitas Islam kebangsaan Indonesia (UNIKI) \\ *) email: m.yusuf@uniki.ac.id
}

DOI:

https://doi.org/10.55178/idm.v2i4.222

ABSTRACT

Article history

Received:

September 11, 2021

Revised:

September 17, 2021

Accepted:

September 20, 2021

Page:

$46-52$

\section{Kata kunci:}

competence, work discipline, work experience, principal's performance
This study aims to examine, 1) the effect of competence on the principal's performance, 2) the influence of work discipline on the principal's performance, 3) the effect of work experience on the principal's performance, and 4) the influence of competence, work discipline and work experience on the principal's performance. SD in Bireuen Regency. The research method used in this study is the associative method with a quantitative approach, to 147 elementary school principals throughout Bireuen Regency, with the collection technique using a closed questionnaire instrument. The analytical method used is a path analysis approach. The results showed that 1) There was a significant influence of the Competency factor on the Principal's Performance, amounting to $8.45 \%$. 2) It is statistically proven that the work discipline factor affects the Principal's Performance by 12.69\%. 3) It is statistically proven that the work experience factor affects the principal's performance, amounting to $7.82 \%$. 4) The results of the correlation coefficient between competence, work discipline and work experience on the principal's performance obtained $R$ of 0.638 explaining the relationship between competence, work discipline, and work experience on performance, has a fairly high level of relationship, and is linearly related, with the degree of relationship of 0.638 . The value of the coefficient of determination of 0.407 explains that the contribution of competence, work discipline, and work experience to the Principal's Performance is $40.7 \%$. While the rest (residual value) of the role of the variables that were not studied was $59.3 \%$. The residual value shows that there are other factors that can affect the performance of school principals throughout Bireuen Regency, such as organizational climate, work facilities, education and training, and others.

\section{Pendahuluan (Introduction)}

Ditetapkannya program "Aceh Carong" dari pemerintah Aceh melalui peraturan daerah, membangkitkan semangat setiap sekolah untuk memacu mutu sekolah dan prestasi sekolah. Dampak ini, minimal membudayakan kompetisi sekolah dan Kepala Sekolah akan memacu diri untuk bersinergi dengan program tersebut memalui kinerjanya dan kinerja sekolah.

Kinerja sekolah dibawah kepemimpinan Kepala sekolah untuk berprestasi, tentunya melalui apa yang telah dikerjakan dan diperolehnya, dengan memenuhi standar pendidikaan yang telah ditetapkan, sehingga akan terukur secara kualitas maupun kuantitas. Kinerja sekolah akan berpulang pada kinerja Kepala Sekolah dalam mengelola dan melaksanakan tugas dan tanggung jawab untuk mencapai tujuan pendidikan disekolahnya secara berkesinambungan.

Oleh karenanya, kepemimpinan Kepala Sekolah seyogyanya dapat menciptakan kondisi-kondisi yang memungkinkan bagi lahirnya iklim kerja dan hubungan antar manusia yang harmonis dan kondusif. Sehingga pada gilirannya dapat timbul gairah semua pemangku kepentingan di dalamnya, dan pada 
akhirnya menghasilkan lulusan dengan kualitas yang diharapkan. Untuk hal itu, memang dibutuhkan kompetensi, kedisiplinan dan pengalaman Kepala sekolah.

Keterlibatan Dinas Pendidikan, Pemuda Dan Olahraga Kabupaten Bireuen dalam memacu kinerja sekolah, Kepala sekolah dan guru, terus diupayakan melalui bimbingan teknis dari masalah implementasi aturan dan regulasi bidang pendidikan, kurikulum dan kompetensi guru. Yang sasarannya semua Kepa Sekolah dapat memahami semua ketentuan dalam mencapai tujuan pendidikan nasional, dan regulasi yang dilakukan di daerah Aceh.

Masih rendahnya prestasi dan nuansa kompetensi yang terjadi pada tingkat Sekolah Dasar di Kabupaten Bireuen, misalnya, peneliti melihat adanya fenomena dari kalangan Kepala Sekolah (dan sebagian guru) yang belum menguasai teknologi informasi, termasuk media aplikasi berbasis komputer, dan hal ini sangat tampak pada saat menjalankan proses pendidikan di masa pandemic covid'19 yang mengharuskan beberapa klaster menggunakan pembelajaran secara online.

Selain kompetensi, disiplin kerja juga dapat mempengaruhi peningkatan kinerja Kepala Sekolah. Kedisplinan adalah kesadaran dan kesediaan seseorang mentaati peraturan dan norma yang berlaku (Hasibuan, 2010:193). Disiplin kerja yang tinggi akan menunjukkan adanya rasa tanggung jawab yang besar yang dimiliki pegawai dalam menyelesaikan tugas-tugas yang diberikan kepadanya. Hal ini sudah diatur oleh pemerintah pada Peraturan Pemerintah Nomor 53 Tahun 2010 serta pengelolaan disiplin juga diatur dalam Surat Edaran Kepala Badan Administrasi Kepegawaian Negara Nomor 23/SE/1980 Tanggal 30 Oktober 1980 tentang Peraturan Displin PNS.

Disiplin kerja Kepala Sekolah Dasar (SD) di Kabupaten Bireuen maupun disiplin waktu, peneliti masih melihat belum terlaksana dengan baik. Dilihat juga saat kita ada urusan di kantor sering kali para Kepala Sekolah Dasar (SD) Di Kabupaten Bireuen yang bersangkutan sulit dijumpai di tempat.

Selain kompetensi dan disiplinkerja faktor lain yang mempengaruhi kinerja Kepala Sekolah adalah pengalaman kerja. Pengalaman kerja merupakan faktor yang mampu memberikan kontribusi positif terhadap peningkatan kinerja pegawai (Kotur dan Anbazhagan, 2014). Hal ini biasanya diukur dari dimensi lama waktu atau masa kerja yang telah ditempuh seseorang sehingga dapat memahami tugas-tugas suatu pekerjaan yang diembannya.

Fenomena yang terjadi pada saat ini adalah Kepala Sekolah Dasar (SD) Di Kabupaten Bireuen dengan pengalaman kerja yang lama, statusnya yang sudah senior, sering kurang mau mengikuti pelatihan, karena merasa sudah mampu.

Adanya fenomena tersebut menarik perhatian peneliti untuk meneliti ulang dengan mengambil judul "Pengaruh Kompetensi, Disiplin Kerja Dan Pengalaman Kerja Terhadap Kinerja Kepala Sekolah Dasar (SD) Se-Kabupaten Bireuen".

\section{Tinjauan Literatur (Literature Review)}

\section{Pengaruh Kompetensi terhadap Kinerja}

Selayaknya aspek kompetensi bagi Kepala sekolah bukan sekedar pengetahuan dan keterampilan (skill). Juga melibatkan kemampuan untuk mengikuti regulasi bidang pendidikandan program pemerintah daerah, seperti dicanang Gubernur dengan program "Aceh Carong", sehingga mampu memobilisasi potensinya dan sekolah untuk mensukseskan hal demikian. Dengan demikian, maka Kepala Sekolah harus mengambil langkah cerdas dan penuh tanggung jawab didasarkan pada pengetahuan, keterampilan dan sikap dalam menjalankan tugas-tugas sesuai dengan pekerjaannya (Farida Sarimaya, 2008, Akhmad Sudrajat, 2008).

Dengan adanya kompetensi yang dimiliki seorang pemimpin, seperti halnya Kepala Sekolah akan berimbas langsung pada kualitas kerjanya untuk memiliki prestasi dan hal itu dibuktikan dengan kinerjanya. Bernardin \& Russell (2005) menjelaskan kinerja merupakan catatan outcome yang dihasilkan dari fungsi pegawai tertentu atau kegiatan yang dilakukan selama periode waktu tertentu.

\section{Pengaruh Disiplin Kerja terhadap Kinerja}

Disiplin selalu menjadi ukuran yang positif dan biasanya dijadikan sebagai indikasi seseorang yang sukses mencapai tujuannya. Hasibuan (2012:193) menyatakan disiplin kerja merupakan instrumen yang penting dalam menunjang kinerja. Sebagaimana dinyatakan Dharmawan (2011:9) "Semakin disiplin, maka semakin tinggi kinerja pegawai dan mempermudah organisasi dalam mencapai tujuannya. 
Karena Kepala Sekolah adalah orang yang dituakan dan diteladani oleh semua unsur sekolah, maka layaknya orang pertama yang harus menegakkan disiplin kerja dan disiplin yang berkaitan dengan aturan sekolah.

\section{Pengaruh Pengalaman Kerja terhadap Kinerja}

Seorang mampu menjadi profesional dan berkinerja tinggi, tidak bisa lepas dari pengalaman kerja yang pernah dilaluinya. Umumnya Kepala Sekolah, sudah lama bekerja sebelumnya yakni dimulai dari statusnya sebagai guru. Dan salah satu karena kepangkatan dan masa kerja yang sudah mumpuni, maka dapat diangkat sebagai Kepala Sekolah. Rata-rata Usia Kepala Sekolah di Sekolah Dasar Kabupaten Bireuen antara 40 - 50 tahun, maknanya sudah cukup lama mereeka bekerja di lingkungan pendidikan Sekolah dasar. Sehingga kemampuan dalam bidang pendidikan dan tugasnya sebagai peneglola pendidikan sudah mumpuni.

Dengan lamanya pengalaman kerja, selayaknua di ikuti dengan kematangan dalam bekerja dan sinergi dengan tingginya kinerja mereka. Sebagaimana dinyatakan Marwansyah (2014) pengalaman kerja sangat penting perannya dalam organisasi. Dengan demikian, pengalaman kerja yang didapat seseorang akan membuat hasil kerja yang dicapai oleh seorang akan lebih baik.

Juga bahwa nilai Kinerja berkaitan dengan proses kerja yang dilakukan sesuai dengan peraturan (secara legal) dan moral atau etika yang berlaku. Oleh karnanya, pengalaman seseorang akan mampu melakukan proses kerja sehingga pada gilkirannya akan memiliki kinerja baik.

\section{Metode Penelitian (Methodology)}

\section{a. Metode dan Variabel Penelitian}

Metode penetian yang akan digunakan dalam penelitian ini adalah metode asosiatif kuantitatif. Sehingga dapat menjelaskan hubungan kausal dan pengaruh antara variabel-variabel melalui pengujian hipotesis atas dasar data kuantitatif.

Penelitian dilakukan terhadap 147 sampel dari 231 Kepala sekolah pada Sekolah Dasar di Kabupaten Bireuen, pada tahun 2020. Dimana instrument penelitian menggunakan angket tertutu dengan 5 pilihan, yakni dimulai dari persetujuan suatu pernyataan sampai tidak setuju, dengan skala linert-5. Pernyataan yang disusun atas dasar dimensi dan indicator dari variable yang diteliti, yakni kompetensi, disiplin kerja dan pengalaman serta kinerja Kepala Sekolah.

Adapun variabel, dimensi dan indikator pengukur setiap variabelnya dinyatakan berikut ini.

Tabel 1. Operasional Variabel Penelitian

\begin{tabular}{|c|c|}
\hline Variabel & Dimensi \\
\hline $\begin{array}{c}\text { Kompetensi } \\
\left(\mathrm{X}_{1}\right) \\
\text { Sumber: Moeheriono (2014:5) }\end{array}$ & $\begin{array}{l}\text { - Pengetahuan } \\
\text { - Keterampilan } \\
\text { - Motif } \\
\text { - Sifat }\end{array}$ \\
\hline $\begin{array}{c}\text { Disiplin kerja } \\
\text { (X2) } \\
\text { Sumber: Hasibuan (2012:193) }\end{array}$ & $\begin{array}{l}\text { - Aturan Waktu } \\
\text { - Taat terhadap peraturan } \\
\text { - Aturan perilaku dalam pekerjaan }\end{array}$ \\
\hline $\begin{array}{c}\text { Penagalaman kerja } \\
\text { (X3) } \\
\text { Sumber: Marihot (2013:120) }\end{array}$ & $\begin{array}{l}\text { - Lama waktu/masa kerja } \\
\text { - Tingkat pengetahuan dan keterampilan yang } \\
\text { dimiliki } \\
\text { - Penguasaan terhadap pekerjaan dan peralata }\end{array}$ \\
\hline $\begin{array}{c}\text { Kinerja } \\
\text { (Y) } \\
\text { Sumber: Wibowo (2011:7). }\end{array}$ & $\begin{array}{l}\text { - Sasaran Kerja Pegawai (SKP) } \\
\text { - Perilaku Kerja }\end{array}$ \\
\hline
\end{tabular}

\section{b. Alat Analisis}

Berkaitan dengan jenis penelitian ini adalah penelitian kuantititatif dengan alat analisis dengan statistik parametrik, yakni Analisis jalur.

Analisis jalur merupakan bentuk pemodelan antar variable terkait, yang akan mengukur pengaruh variable eksegenoues terhadap variable endogenous, sesuai dengan modifikasi dari Harun dalam Nirwana (2014). 
Menurut Pedhazur (1982) dalam Marwan Hamid, dkk (2019), bahwa tujuan analisis jalur adalah apakah model yang diusulkan cocok atau tidak dengan data, yaitu dengan cara membandingkan matriks korelasi teoritis dengan matriks korelasi empiris. Jika kedua matriks relatif sama, maka model dikatakan "cocok" atau fit.

Untuk dapat menggunakan alat analisis ini, juga menuntut jaminan atau syarat statistik parametrik yakni terpenuhinya semua asumsi klasik, yaitu asumsi normalitas, heterosidasitas, multikolinieritas dan autokorelasi.

\section{Hasil dan Pembahasan (Results and Discussion)}

\section{a. Karakteristik Responden Penelitian}

Karakteristik responden menggambarkan kondisi Kepala Sekolah dari sisi umur hingga lama kerja, yakni dicantumkan dalam tabel berikut :

Tabel 2. Diskripsi Responden Kepala Sekolah SD

\begin{tabular}{|c|l|c|c|}
\hline \multicolumn{2}{|c|}{ Keterangan } & Jumlah & Persentase (\%) \\
\hline \multirow{4}{*}{ Umur } & $\leq 35$ tahun & 2 & 1.36 \\
\cline { 2 - 4 } & $36-45$ tahun & 29 & 19.73 \\
\cline { 2 - 4 } & $>45$ tahun & 116 & 78.91 \\
\hline \multirow{3}{*}{ Jenis Kelamin } & Laki - Laki & 84 & 57.14 \\
\cline { 2 - 4 } & Perempuan & 63 & 42.86 \\
\hline \multirow{3}{*}{$\begin{array}{c}\text { Pendidikan } \\
\text { Terakhir }\end{array}$} & SMA/SMK & 0 & 0.00 \\
\cline { 2 - 4 } & D3 & 0 & 0.00 \\
\cline { 2 - 4 } & S1 & 143 & 97.28 \\
\cline { 2 - 4 } & S2 & 4 & 2.72 \\
\hline \multirow{2}{*}{ Lama kerja } & $\leq 15 \mathrm{Th}$ & 0 & 0.00 \\
\cline { 2 - 4 } & $16-20 \mathrm{Th}$ & 127 & 18.37 \\
\cline { 2 - 4 } & $>20 \mathrm{Th}$ & 147 & 81.63 \\
\hline \multicolumn{2}{|c|}{ Jumlah Responden } & & 100 \\
\hline
\end{tabular}

Sumber : Data Primer yang diolah, 2020

\section{b. Hasil analisis Deskriptif}

Hasil survey menggunakan angket dari variabel penelitian diperoleh informasi sebagai berikut.

Tabel 3. Deskripsi Penilaian Pegawai tentang Variabel Penelitian

\begin{tabular}{|c|c|c|c|c|c|c|}
\hline \multirow{2}{*}{ Variabel } & \multicolumn{5}{|c|}{ Persentase Jawaban setiap item (Jumlah) } & \multirow{2}{*}{$\begin{array}{c}\text { Skor } \\
\text { Pencapaian }\end{array}$} \\
\hline & STS & TS & KS & $\mathrm{S}$ & SS & \\
\hline \multirow{2}{*}{ - Kompetensi } & 0 & 23 & 199 & 518 & 142 & \multirow{2}{*}{77,64} \\
\hline & 0.00 & 2.61 & 22.56 & 58.73 & 16.10 & \\
\hline \multirow{2}{*}{ - Disiplin kerja } & 0 & 5 & 178 & 407 & 145 & \multirow{2}{*}{78,83} \\
\hline & 0.00 & 0.68 & 24.22 & 55.37 & 19.73 & \\
\hline \multirow{2}{*}{ - Pengalaman kerja } & 0 & 12 & 260 & 494 & 116 & \multirow{2}{*}{76,19} \\
\hline & 0.00 & 1.36 & 29.48 & 56.01 & 13.15 & \\
\hline
\end{tabular}

Sumber : Hasil Peneltian, 2020 (data diolah)

Berdasarkan tabel di atas dapat dijelaskan bahwa :

1. Kompetensi Kepala Sekolah, tentang pengetahuan menggunakan alat/media, kemampuan melaksanakan dan menyelesaikan pekerjaan, keterampilan bekerja sama dan menyelesaikan tugas, serta tanggap dan dapat menyelesaikan masalah. Menurut olahan data diatas, terdapat paling banyak yang menjawab setuju $(58,73 \%)$ bahwa Kepala Sekolah memiliki pengetahuan dan ketermapilan serta sikap tanggap akan pekerjaannya. Atas dasar ini, diperoleh pencapaian kompetensi Kepala Sekolah sebesar 77,64\% Hal ini masuk kategori baik. walaupun masih harus dioptimalkan lagi.

2. Disiplin kerja Kepala Sekolah, berkaitan dengan kehadiran bekerja, mampu melaksanakan beban kerja dan kerjasama, dan perinsip penegakan disiplin sekolah. Menurut persepsi responden paling banyak menjawab setuju $(55,37 \%)$. Secara total pencapaian aspek disiplin kerja sudah baik, mencapai $78,83 \%$, walaupun masih bisa dan harus ditingkatkan lagi. 
3. Pengalaman kerja Kepala Sekolah dari penilaian aspek pengalaman dalam menyelesaikan pekerjaan, sikap profesional, melaksanakan tugas sesuai prosedur, meminimalkan kesalahan yang terjadi dalam pekerjaan. Menurut responden, paling banyak menjawab setuju $(56,01 \%)$ dan secara keseluruhan pencapaian tentang pengalaman kerja dalam mendukung kinerja ini mencapai 76,19\%, hal ini dianggap baik.

\title{
c. Hasil Analisis Jalur
}

Dengan pendekatan analisis jalur, yakni kombinasi regresi variabel bebas terhadap variabel tak bebas (Kinerja) dan adanya hubungan kausalitas antar variabel bebas $\left(\mathrm{r}_{\mathrm{xi}, \mathrm{xj}}\right)$, dinyatakan dalam gambar 1 berikut:

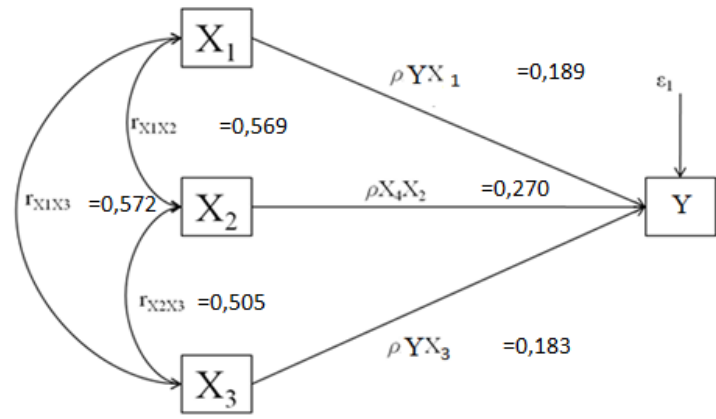

\author{
Keterangan : \\ $\mathrm{Y}=$ Kinerja \\ $\mathrm{X} 1=$ Kompetensi \\ $\mathrm{X} 2=$ Displin kerja \\ X3 = Pengalaman kerja
}

Gambar 1 Diagram Jalur Penelitian

\section{d. Uji Model}

Hipotesis 1: Kompetensi berpengaruh terhadap Kinerja Kepala Sekolah

Hasil perhitungan uji individu menunjukkan harga $t_{\text {hitung }}$ sebesar 2,025 yang lebih besar dari t-tabel $=1,658$, dan nilai ini signifikans pada taraf uji 0,045 atau 4,5\%. Sehingga Ho ditolak dan Ha diterima artinya koefisien jalur Kompetensi berpengaruh terhadap Kinerja Kepala Sekolah.

Hipotesis 2: Disiplin kerja berpengaruh terhadap Kinerja Kepala Sekolah

Hasil uji menunjukkan harga $t_{\text {hitung }}$ sebesar 3,036. Dengan demikian $t_{\text {hitung }}>t_{\text {tabel }}(3,036>1,658)$, dan nilai ini juga signifikansi dari hasil olahan data pada taraf uji 0,003 atau $0,3 \%$. Sehingga koefisien jalur variabel disiplin kerja signifikans pada taraf signifikan $\alpha=0,05$. Maka terdapat pengaruh secara signifikan disiplin kerja terhadap Kinerja Kepala Sekolah.

Hipotesis 3 : Pengalaman kerja berpengaruh terhadap Kinerja

Hasil perhitungan diperoleh $t_{\text {hitung }}$ sebesar 2,054 Dengan demikian $t_{\text {hitung }}>t_{\text {tabel }}(2,054>1,658)$. Sehingga koefisien jalur variabel pengalaman kerja berpengaruh terhadap terhadap Kinerja Kepala Sekolah.

\section{e. Hasil Analisis Pengaruh Variabel dan Pembahasan}

\section{1). Pengaruh Kompetensi terhadap Kinerja Kepala Sekolah}

Besar Pengaruh langsung:

Besarnya pengaruh langsung Kompetensi, dengan besaran koefisien jalur $\left(\rho_{\mathrm{yx} 1}=0,189\right)$, Sehingga besarnya pengaruh langsung ini adalah: $(0,189)^{2} \times 100 \%=3,57 \%$.

Besar Pengaruh Tidak langsung

Besarnya pengaruh tidak langsung Kompetensi di hitung masing-masing berikut ini:

- Pengaruh Kompetensi melalui disiplin kerja, adalah $=(0,189)(0,569)(0,270) \times 100 \%=2,90 \%$

- Pengaruh Kompetensi melalui Pengalaman kerja adalah $=(0,189)(0,572)(0,183) \times 100 \%=1,98 \%$

Pengaruh Total Kompetensi

Berdasarkan hal diatas, maka total pengaruh Kompetensi terhadap Kinerja Kepala Sekolah, melalui disiplin kerja dan pengalaman kerja, yakni: 3,57\% + 2,90\% +1,98\%, diperoleh sebesar 8,45\%.

\section{2). Pengaruh Disiplin kerja terhadap Kinerja Kepala Sekolah}

Besar Pengaruh langsung

Besarnya pengaruh langsung Disiplin kerja, dengan besaran koefisien jalur $\left(\rho_{\mathrm{yx} 2}=0,270\right)$, Sehingga besarnya pengaruh langsung ini adalah: $(0,270)^{2} \times 100 \%=7,29 \%$. 
Besar Pengaruh Tidak langsung

Besarnya pengaruh tidak langsung disiplin kerja, dinyatakan berikut ini:

- Pengaruh disiplin kerja melalui Kompetensi, adalah $(0,270)(0,569)(0,189) \times 100 \%=2,90 \%$

- Pengaruh Disiplin kerja melalui pengalaman kerja adalah $(0,270)(0,505)(0,183) \times 100 \%=2,50 \%$

Pengaruh Total Disiplin kerja

Berdasarkan hal diatas, maka total pengaruh disiplin kerja, melalui Kompetensi dan pengalaman kerja, yakni: $7,29 \%+2,90 \%+2,50 \%$, diperoleh sebesar $12,69 \%$

\section{3). Pengaruh Pengalaman kerja terhadap Kinerja Kepala Sekolah}

\section{Besar Pengaruh langsung}

Besarnya pengaruh langsung dengan koefisien jalur $\left(\rho_{\mathrm{yx} 3}=0,183\right)$, maka $(0,183)^{2} \times 100 \%=3,35 \%$.

Besar Pengaruh Tidak langsung

Besarnya pengaruh tidak langsung pengalaman kerja, dinyatakan dengan perhitungan berikut:

- Pengaruh Pengalaman kerja melalui Kompetensi, adalah $(0,183)(0,572)(0,189) \times 100 \%=1,98 \%$

- Pengaruh Pengalaman kerja melalui Disiplin kerja, adalah $(0,183)(0,505)(0,270) \times 100 \%=2,50 \%$

Pengaruh Total Pengalaman kerja

Berdasarkan hal diatas, maka total pengaruh pengalaman kerja terhadap Kinerja kepala Sekolah, melalui kompetensi dan disiplin kerja, yakni: 3,35\% + 1,98\% + 2,50\% , diperoleh sebesar 7,82 \% .

\section{4). Analisis Pengaruh Kompetensi, Disiplin kerja dan Pengalaman kerja terhadap Kinerja}

Analisis ini menggunakan hasil model jalur yakni : $Y=0,189 X_{1}+0,270 X_{2}+0,183 X_{3}$

$$
\left(\mathrm{Y}=\text { Kinerja, } \mathrm{X}_{1}=\text { Kompetensi, } \mathrm{X}_{2}=\text { Disiplin kerja, } \mathrm{X}_{3}=\text { Pengalaman kerja }\right)
$$

Maka dari persamaan tersebut dapat dijelaskan bahwa koefisien jalur kompetensi bernilai positif $(0,189)$ artinya apabila kemampuan pengetahuan dan keterampilan dalam bekerja sebagai ukuran kompetensi Kepala Sekolah di tingkatkan sekitar 10 persen akan dapat mendukung kinerja dalam bekerja sebagai Kepala Sekolah sebesar 1,89 persen lebih meningkat secara rata-rata.

Untuk variabel disiplin kerja juga bernilai positif $(0,270)$ artinya dengan menerapkan disiplin kerja sesuai aturan terhadap semua beban kerja Kepala Sekolah yang lebih baik akan meningkatkan kinerjanya. Dengan rata-rata peningkatan disiplin kerja $10 \%$ akan dengan sendirinya akan meningkat kinerja Kepala Sekolah sebesar rata-rata 2,70 persen.

Koefisien jalur pengalaman kerja yang dimiliki Kepala Sekolah bernilai positif $(0,183)$ artinya kinerja Kepal Sekolah dipengaruhi juga oleh pengalaman kerjanya. Dengan rata-rata pengaruhnya sebesar 1,83 persen setiap adanya kenaikan $10 \%$ dari pengalaman kerja kepala sekolah.

Selain hal diatas, memperhatikan nilai koefisien korelasi sebagaiman dinyatkan Ghozali (2012), maka dapat menjelaskan hubungan antar variable dan kontribusinya. Untuk itu, maka meninjau hasil tabel 4 berikut:

Tabel 4. Koefisien Korelasi Simultan

\begin{tabular}{|c|c|c|c|c|}
\hline Model & R & R Square & Adjusted R Square & Std. Error of the Estimate \\
\hline Jalur & 0.638 & 0.407 & 0.412 & 1.50052 \\
\hline
\end{tabular}

Sumber: Data Primer, 2020 (diolah dengan SPSS).

Dapat menjelaskan bahwa kontribusi aspek kompetensi, disiplin kerja, dan pengalaman kerja terhadap Kinerja Kepala Sekolah sebesar 40,7\%. Sementara sisanya (nilai residu) dari peran variabel yang tidak diteliti sebesar 59,3\%.

\section{Simpulan (Conclusion)}

\section{1). Analisis Kajian Deskriptif}

Hasil analisis data penelitian, secara deskriptif yang menggambarkan kondisi setiap variabel, dinyatakan berikut ini:

a. Variabel Kompetensi Kepala Sekolah, yang berkaitan dengan Kepala Sekolah memiliki pengetahuan dan ketermapilan serta sikap tanggap akan pekerjaannya. Diperoleh pencapaian kompetensi Kepala Sekolah sebesar 77,64\% Hal ini masuk kategori baik. walaupun masih harus dioptimalkan lagi. 
b. Variabel disiplin kerja Kepala Sekolah, berkaitan dengan kehadiran bekerja, mampu melaksanakan beban kerja dan kerjasama, dan prinsip penegakan disiplin sekolah. Diperoleh hasil pencapaian aspek disiplin kerja sudah baik, mencapai 78,83\%, walaupun masih bisa dan harus ditingkatkan lagi.

c. Variabel pengalaman kerja Kepala Sekolah dari penilaian aspek pengalaman dalam menyelesaikan pekerjaan, sikap profesional, melaksanakan tugas sesuai prosedur, meminimalkan kesalahan yang terjadi dalam pekerjaan. Secara keseluruhan pencapaian tentang pengalaman kerja dalam mendukung kinerja ini mencapai 76,19\%, hal ini dianggap baik.

\section{2). Analisis Verifikatif}

a. Terbukti secara statistik bahwa Kompetensi berpengaruh terhadap Kinerja Kepala Sekolah, melalui disiplin kerja dan pengalaman kerja, yakni sebesar $8,45 \%$.

b. Terbukti secara statistik bahwa faktor disiplin kerja berpengaruh terhadap Kinerja Kepala Sekolah, melalui Kompetensi dan pengalaman kerja, yakni sebesar 12,69\%.

c. Terbukti secara statistik bahwa faktor pengalaman kerja berpengaruh terhadap Kinerja kepala Sekolah, melalui kompetensi dan disiplin kerja, yakni sebesar 7,82\%.

d. Hubungan kompetensi, disiplin kerja dan pengalaman kerja terhadap kinerja Kepala Sekolah ditunjukkan oleh statistik $R$ sebesar 0,638 yang masuk kategori tinggi. Sehingga statistic R-square 0,407 menjelaskan bahwa kontribusi faktor kompetensi, disiplin kerja, dan pengalaman kerja terhadap Kinerja Kepala Sekolah sebesar 40,7\%. Sisanya peran variabel yang tidak diteliti sebesar 59,3\%, diantaranya faktor iklim organisasi, fasilitas kerja, Pendidikan dan Pelatihan, dan lain-lain.

\section{DAFTAR PUSTAKA (References)}

1) Akhmad Sudrajat. 2008. Pengertian Pendekatan, Strategi, Metode, Teknik dan. Model Pembelajaran. Bandung : Sinar Baru

2) Bernardin and Russel. 2005. .Human Resource Management, An. Experimential Approach, terjemahan.Jakarta: Pustaka Binaman Presindo

3) Dharmawan, Yusa. 2011. Pengaruh Kompensasi dan Lingkungan Kerja Non Fisik Terhadap Disiplin dan Kinerja Karyawan Hotel Nikki Denpasar. Tesis. Universitas Udayana.

4) Enceng, Liestyodono dan Purwaningdyah, 2008. Meningkatkan Kompetensi Aparatur Pemerintah Daerah dalam Mewujudkan Good Governance. Jurnal Kebijakan dan Manajemen PNS. Vol 2 Juni 2008: 12-15.

5) Farida, Sarimaya. 2008, Sertifikasi Guru, Apa, Mengapa dan Bagaimana?, Bandung: Penerbit Yrama Widya.

6) Ghozali, Imam. 2012. Aplikasi Analisis Multivariate dengan Program IBM SPSS. Yogyakarta: Universitas Diponegoro

7) Hasibuan, Malayu S.P. 2010. Manajemen Sumber Daya Manusia. Jakarta: PT Bumi. Aksara.

8) Hasibuan, Malayu S.P. 2012. Manajemen SDM. Edisi Revisi, Cetakan Ke. Tigabelas. Jakarta : Bumi Aksara.

9) Kotur, B. R., \& Anbazhagan, S. 2014. Education and Work-Experience - Influence on the Performance. IOSR Journal of Business and Management (IOSR-JBM) Vol. 16, Issue. 5, Ver. III, May 2014, PP. 104-110.

10) Marwan Hamid, Ibrahim Sufi, Win Konadi, dan Yusrizal Akmal, 2019. Analisis Jalur Dan Aplikasi Spss Versi 25, Edisi Pertama Sefa Bumi Persada, Medan.

11) Marwansyah. 2014. Manajemen Sumber Daya Manusia, Edisi Kedua, Alfabeta,. Bandung.

12) Marihot, Manullang. 2013. Manajemen Sumber Daya Manusia. Yogyakarta: BPFE.

13) Moeheriono. 2009. Pengukuran Kinerja Berbasis Kompetensi. Bogor: Ghalia Indonesia.

14) Nirwana Sari. A.B. 2014. Perbandingan Model Regresi Cox Menggunakan Time-Dependent Variable dan Stratified Proportional Hazard untuk Mengatasi Nonproportional Hazard. Jurnal Statistik FMIPA Universitas Brawijaya 2(1): 69-72.

15) Sutrisno Edy, 2016. Manajemen Sumber Daya Manusia. Cetak Ke-7. Pranada Media Group. Jakarta.

16) Wibowo. 2006. Manajemen Perubahan. Jakarta : Raja Grafindo Persada. 